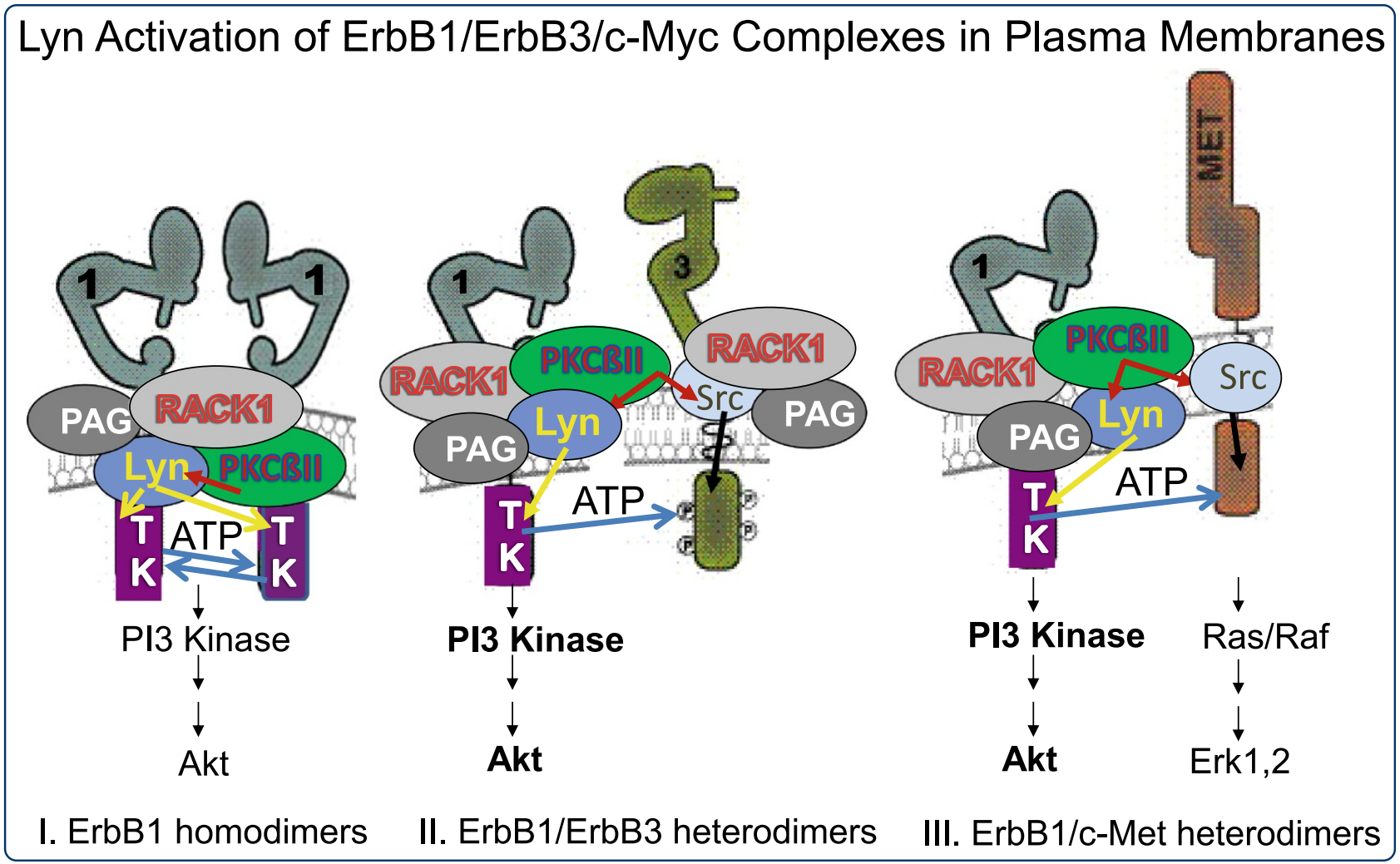

\title{
Lyn, a Src family kinase, regulates activation of epidermal growth factor receptors in lung adenocarcinoma cells
}

Sutton et al. 


\title{
Lyn, a Src family kinase, regulates activation of epidermal growth factor receptors in lung adenocarcinoma cells
}

\author{
Parnetta Sutton ${ }^{1,2}$, Jeffrey A Borgia ${ }^{3}$, Philip Bonomi ${ }^{2}$ and Janet MD Plate ${ }^{2,4^{*}}$
}

\begin{abstract}
Background: Activation of receptors for growth factors on lung epithelial cells is essential for transformation into tumor cells, supporting their viability and proliferation. In most lung cancer patients, EGFR is constitutively activated without evidence of mutation. Defining mechanisms for constitutive activation of EGFR could elucidate additional targets for therapy of lung cancers.

Methods: The approach was to identify lung cancer cell lines with constitutively activated EGFR and use systematic selection of inhibitors to evaluate their effects on specific EGFR phosphorylations and downstream signaling pathways. Interactions between receptors, kinases, and scaffolding proteins were investigated by coimmunoprecipitation plus Western blotting.

Results: The results revealed a dependence on Src family of tyrosine kinases for downstream signaling and cell growth. Lyn, a Src family kinase functional in normal and malignant B-lymphocytes, was a defining signal transducer required for EGFR signaling in Calu3 cell line. Src family kinase activation in turn, was dependent on PKCBII. Lyn and PKC exist in membrane complexes of RACK1 and in association with EGFR which pairs with other receptor partners. Silencing of Lyn expression with interfering siRNA decreased EGFR activation and cell viability.

Conclusions: The importance of Src family kinases and PKCBII in the initiation of the EGFR signaling pathway in lung tumor cells was demonstrated. We conclude that phosphorylation of EGFR is mediated through PKCBII regulation of Lyn activation, and occurs in association with RACK1 and Cbp/PAG proteins. We suggest that protein complexes in cell membranes, including lipid rafts, may serve as novel targets for combination therapies with EGFR and Src Family Kinase inhibitors in lung cancer.
\end{abstract}

Keywords: Lung adenocarcinoma cells, Epidermal growth factor receptors, Src family kinases, Lyn, Membraneassociated protein complexes/lipid rafts, RACK1, Cbp\PAG

\section{Introduction}

The ErbB epidermal growth factor family of receptors (EGFR) is often upregulated, amplified, mutated, or overexpressed in cancer cells [1-3]. EGFR is a homodimer of ErbB1, but different family members can heterodimerize with ErbB1 to yield functional partners, some more active than EGFR itself (reviewed in $[2,4]$ ), [5]. Immunohistochemical staining of normal human

\footnotetext{
* Correspondence: jmdplate27@gmail.com

2Division of Oncology, Department of Medicine, Hematology and Cell

Therapy, Rush University Medical Center, Chicago, IL 60612, USA

${ }^{4}$ Department of Immunology \& Microbiology, Rush University Medical

Center, Chicago, IL 60612, USA

Full list of author information is available at the end of the article
}

bronchial epithelium detects ErbB1, ErbB2 (HER2/Neu), and ErbB3 (HER3) [6]. The signaling pathways triggered by EGFR are critical to lung cancer as blocking with specific inhibitors results in cell death [7-12]. ErbB1 chains contain intracellular tyrosines some of which become autophosphorylated by dimerization and serve as docking sites for adaptor proteins that convey signals downstream thus promoting cell survival, angiogenesis, migration and tumor cell invasion [13,14]. Additional phosphorylations of EGFR by other kinases stabilize and enhance receptor activity $[4,15]$. The importance of EGFR kinase activity in lung cancer is illustrated by the approval of tyrosine kinase inhibitors (TKIs) as

\section{Biomed Central}


therapeutic agents. TKIs competitively bind and inhibit the catalytic kinase domain preventing EGFR from initiating signal transduction. Targeting EGFR in lung cancer is particularly successful in patients with activation mutations in ErbB1, while other NSCLC patients either are partially responsive, have disease stabilization, or do not respond at all [16-21]. Approximately $15 \%$ of tumors in lung cancer patients exhibit EGFR activating mutations and have significant responses to TKIs targeting EGFR. Resistant to EGFR inhibitors occurs and is associated with activation of additional signaling pathways, or secondary mutations in the ErbB1 gene that make EGFR less susceptible to inhibitors [20,22-27]. Resistance and lack of responsiveness in the majority of metastatic lung cancer patients emphasize the importance of identifying additional targets for drug therapy. In some tumor cell lines, EGF receptors are activated by unknown mechanisms, hence we reasoned that cell lines could be used to define additional proteins to target. Our approach was to delineate mechanisms of constitutive phosphorylation of EGFR in lung adenocarcinoma cell lines. In preliminary studies constitutive phosphorylation of the EGFR at Y-845 and Y-992 in the Calu3 cell line was found independent of EGF stimulation. The objective of this study thus, was to determine the mechanisms leading to constitutive phosphorylation of EGFR. Once the mechanisms are defined, then inhibitors can be selected to counteract constitutive receptor activation.

\section{Materials and methods \\ Cell lines}

Lung adenocarcinoma lines A549, A427, H2122, H1299, H1975 and Calu3 were obtained from ATCC. A549, A427 and Calu3 were grown in DMEM high glucose medium (Invitrogen) plus 10\% fetal bovine serum (Gemini) and supplements of Minimal Nonessential Mineral \& Vitamins, HEPES buffer, L-glutamine (Invitrogen) as recommended plus $0.75 \mu \mathrm{g}$ gentimycin/ ml. H1975, H1299, H2122 were grown in RPMI 1640 high glucose medium plus 10\% FBS and $0.75 \mu \mathrm{g}$ gentimycin $/ \mathrm{ml}$. Adherent cells were grown to confluency in T-25 or T-75 tissue culture flasks, washed in PBS, then detached with Cell Dissociation Buffer (Invitrogen). For inhibitor studies, Calu3 cells were seeded at 500,000 cells/well while H1975 cells were seeded at 750,000 cells/well and allowed to adhere overnight to achieve $80-90 \%$ confluency before serum starvation for 6 hours to overnight. Cells were treated with various inhibitors or solvent vehicles in serum-free medium as indicated.

\section{Reagents}

AG1478 Tyrphostin (AG) (EGFR tyrosine kinase inhibitor), SU11274 (SU) (c-Met tyrosine kinase inhibitor),
Diphtheria toxin mutant CRM197 [blocks HB-EGF and amphiregulin (AR)], and myristoylated PKCßII peptide inhibitor I (Sigma); erlotinib (Erl) [EGFR tyrosine kinase inhibitor, (Tarceva ${ }^{\mathrm{Tm}}$ ) Genentech/Roche \& OSI]; U0126 (U0) (MEK, and downstream Erk1/2 kinase inhibitor), and human recombinant EGF, [Cell Signaling Technology, Inc (CST)]; PP2 (Src-tyrosine kinase inhibitor), GM6001 (pan-metalloproteinase inhibitor) and TAPI (ADAM17 inhibitor) (Calbiochem); and Enzastaurin (LY317615, ENZA), [serine threonine kinase inhibitor of PKCß, (Lilly Oncology)]. Erlotinib (Tarceva ${ }^{\mathrm{Tm}}$ ) and LY317615 (Enzastaurin) were obtained through Materials Transfer Agreements with OSI and Roche/ Genentech, and with Lilly Oncology, respectively.

\section{Calcein AM proliferation assay}

Cells were seeded at 15,000 cells per well into 96-well flat bottom plates. After adherence and serum starvation overnight, drugs or siRNA were diluted in serum free medium, and added to wells in triplicate then incubated at $37^{\circ} \mathrm{C}, 5 \% \mathrm{CO}_{2}$ for $4-6$ hours before an equal volume of Opt-MEM medium with 10\% FBS but without antibiotics was added, then cultured for the length of times indicated. Two hours before harvesting, $100 \mu \mathrm{l}$ of $4 \mu \mathrm{M}$ $\mathrm{BD}^{\mathrm{m}}$ Calcein $\mathrm{AM}$ was added to washed cells. Plates were read at $485 \mathrm{~nm}$ and relative fluorescence units (RFU) recorded. RFU of ten replicate wells were averaged and analyzed for significance. Mann Whitney unit analysis test was applied to relative fluorescent units (RFU) data from 10 replicate wells and $\mathrm{p}$ values are reported.

\section{Antibodies}

Anti-EGFR, anti-phospho-EGFR (Y-845), anti-phospho-EGFR (Y-992), anti-phospho-EGFR (Y-1068), anti-phospho-HER3/ErbB3 (Y-1289), anti-phospho-Akt (Ser-473), anti-Akt, anti-phospho-GSK-3ß (Ser-21/9), anti-phospho-Src (Y-416), anti-Fyn, anti-Lyn, anti-Yes, anti-Lck, anti-Hck, anti-phospho-Lyn (Y507), anti- $\beta$ Actin and anti-phospho-p44/42 MAP kinase (Thr-202/ Y-204) antibodies (Cell Signaling Technology); antiErbB2/HER2, anti-ErbB-3/HER3-clone 2 F12, antiphospho-PKC $3 \mathrm{II}$ (Y-641), and anti-human EGFR neutralizing antibody (LA1, Upstate Biotechnology); anti-phospho-c-Met (Y-1230,1234,1235) antibody (Invitrogen); mouse anti-RACK1 antibody (BD Biosciences); and rabbit anti-RACK1 and anti-Cbp/PAG antibodies (Santa Cruz Biotechnology). Mouse anti-Lyn, clone 10A6.2, and Milliplex ${ }^{\circledR}$ assays were from Millipore. Horse radish peroxidase conjugated secondary antibodies were: goat anti-rabbit Ig and goat anti-mouse Ig antibodies (Southern Biotech), anti-rabbit light chain TrueBlot ${ }^{\circledR}$ antibodies and anti-rabbit light chain TrueBlot IP beads ${ }^{\circledR}$ (E-Bioscience). 


\section{Cell lysates}

Inhibitors or equal volumes of DMSO solvent vehicle were added to adherent, serum-starved cells in 6-well plates before preparation of cell lysates. Where indicated, cells were stimulated with 500 or $100 \mathrm{ng} / \mathrm{ml}$ of human EGF (CST) for five-ten minutes at $37^{\circ} \mathrm{C}$ before medium was removed, and chilled cell lysis buffer immediately added. Dissolving cells were sonicated 15 seconds before microcentrifugation for 20 minutes. Supernatants were removed and protein concentrations quantitated using Bio-Rad Bradford protein assay. Generally 20-30 $\mu \mathrm{g}$ of protein were loaded into $7.5 \%$ Tris- $\mathrm{HCl}$ pre-cast SDS-PAGE gels (BioRad).

\section{MILLIPLEX ${ }^{\circledR}$ MAP 8-Plex phospho-Src (Tyr419) family kinase immunoassay}

Quantitative sandwich immunobead assays (Millipore) were used to identify Y-419 phosphorylated SFK members including Src, Yes, Fyn, Fgr, Lck, Hck, Blk and Lyn. Cell-free lysates of unstimulated NSCLC cell lines were incubated with specific antibody conjugated beads which select a SFK member, followed by addition of biotiny lated pan-anti-phospho-Src (Y419) to quantify the level of Y-419 phosphorylation of that SFK member. Samples were read in a luminex 100 reader after addition of PE-conjugated StrepAvidin. All assays were performed and analyzed with respect to a standard curve of Hela or Ramos cell lysates according to manufacturer recommended protocols.

\section{Western blotting}

SDS-PAGE were performed using pre-cast $7.5 \%$ Tris- $\mathrm{HCl}$ gel (Bio-Rad) and electrophoresed in Tris Glycine-SDS buffer at 100 volts for 99 minutes. Separated proteins at $20-30 \mu \mathrm{g} /$ lane were transferred to PVDF membranes using a semi-dry transfer apparatus (BioRad). Blotted membranes were washed, blocked overnight on a rocker at $4^{\circ} \mathrm{C}$, then incubated with $1: 1000$ primary antibody diluted in SignalBoost ${ }^{\mathrm{Tm}}$ (Calbiochem), $5 \%$ BSA, or 5\% milk in TBST. Secondary antibodies were added at 1:2000 for 2 hours at $25^{\circ} \mathrm{C}$. ECL substrate (Amersham Biosciences) was added, then blots exposed to film before developing. Anti-actin was used to control for equal protein loading after other antibodies were analyzed as stripping anti-phospho-blots and probing with anti-EGFR for example was not a reliable method.

\section{Immunoprecipitation}

Two-five hundred $\mu \mathrm{g}$ of cell lysate proteins were incubated with $4 \mu \mathrm{g}$ of antibody overnight on a rotator at $4^{\circ} \mathrm{C}$. Recombinant Protein A/G ultra-link resin (Pierce) or Trueblot $^{\circledR}$ anti-light chain IP beads (eBioscience) were washed and added at 1:10 ratio of beads to lysate volumes, then mixed further for $2-3$ hours at $4^{\circ} \mathrm{C}$.
Immunoprecipitation mixtures were microcentrifuged for thirty seconds, the beads washed, then pellets resuspended in 20-65 $\mu \mathrm{l} 2 \mathrm{x}$ sample loading buffer, boiled, cooled, and microcentrifuged before loading 10-15 $\mu \mathrm{l}$ into SDS-PAGE gels.

\section{si-RNA transfection}

Lyn siRNA (LYN ON-TARGET plus SMART pool) and negative control siRNA [ON-TARGET plus NonTargeting siRNA pool, (Dharmacon)] were diluted to $250 \mathrm{nM}$ in antibiotic free OPTI-MEM with Glutamax (Invitrogen) and mixed with an equal volume of transfection reagent (DharmaFECT 2 diluted 1:40 in OPTIMEM) then incubated 20 minutes at room temperature with shaking before $1.0 \mathrm{ml}$ of each mixture was added to cells adhered to duplicate wells of a 6-well plate. Another $1.0 \mathrm{ml}$ of OPTI-MEM containing $10 \%$ FBS but no antibiotics was added after $4-6$ hours at $37^{\circ} \mathrm{C}$, then the plates were incubated for 48, 72, 96, and 144 hours as noted. The kinetics and effectiveness of Lyn siRNA knock-down was confirmed by Western blotting with anti-Lyn or anti-phospho-Lyn. The sequences of the four Lyn siRNAs in the SMARTpools were 1) UUACAU CUCUCCACGAAUC; 2) GAGAUCCAACGUCCAAUA A; 3) GUGAUGUUAUUAAGCACUA and 4) GCGA CAUGAUUAAACAUUA. The protocol to determine the effect of Lyn siRNA knock-down on Calu3 cell viability was modified to ten replicate wells in 96-well plates of Calcein AM assay as described above.

\section{Results}

\section{Constitutive phosphorylation of EGFR in NSCLC cell lines}

Constitutive phosphorylation of EGFR at Y-845 in Calu3 and H1975 cell lines, and at Y-992 was seen in Calu3, H1975, and A549 cell lines (Figure 1A). CLL cells did not express EGFR and nonspecific staining with anti-phosphoEGFR antibodies was not observed. PCR and SSCP assays did not detect activating mutations in Calu3 cells in exons 19 and 21 of the $e r b B 1$ gene (data not presented and [28]), hence Calu3 served as the target of our investigations. H1975 cells on the other hand contain an activating mutation in exon 21 resulting in EGFR phosphorylation.

To investigate mechanisms of constitutive activation of EGFR, autophosphorylation was inhibited with EGFRtyrosine kinase inhibitor AG1478, and later confirmed with erlotinib. Phosphorylation of Y-992 and Y-845 of EGFR were still detectable in unstimulated, serum starved Calu3 cells confirming that they are not autophosphorylation sites, but are phosphorylated by upstream kinases (Figure $1 \mathrm{~B}$ and data not presented) $[29,30]$. AG1478 was functional as it inhibited downstream phosphorylation of Akt (Ser-473). Ligands were not responsible for constitutive phosphorylation of EGFR in unstimulated, serum starved Calu3 cells as 


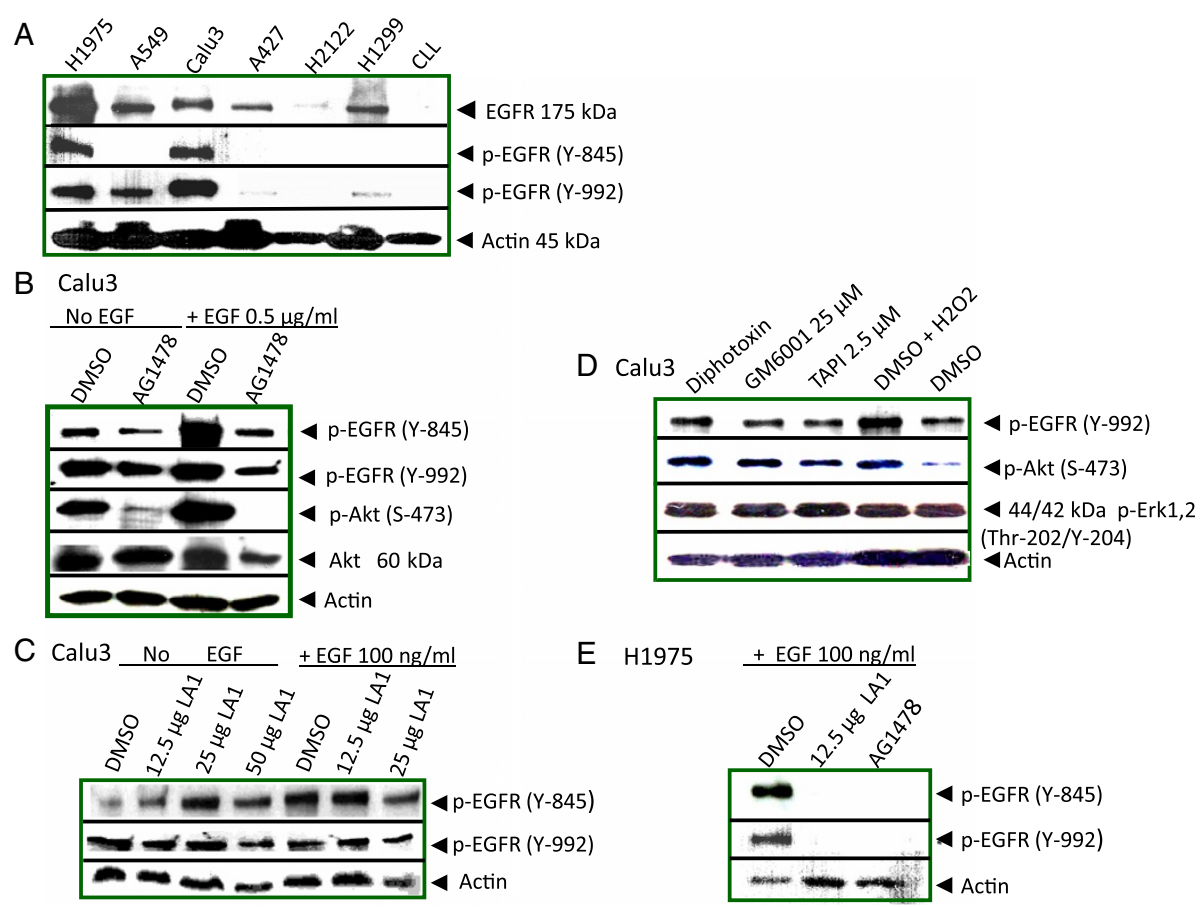

Figure 1 Constitutive phosphorylation of EGFR in non-small cell lung cancer cell lines (NSCLC). (A) Constitutive phosphorylation of EGFR at Y-845 and Y-992. Western blots from lysates of unstimulated NSCLC cell lines and chronic lymphocytic leukemia (CLL) cells were probed with anti-phospho-EGFR (Y-845), anti-phospho-EGFR (Y-992), anti-EGFR or anti-actin antibodies as loading controls. (B) EGFR triggered autophosphorylation is not responsible for constitutive EGFR (Y845) or (Y-992) phosphorylation in Calu3. Calu3 cells were incubated with EGFR kinase inhibitor @ $1 \mu \mathrm{M}$ AG1478, or an equal volume of DMSO solvent, for 1 hour with or without addition of $0.5 \mu \mathrm{g}$ EGF in the final 10 minutes before lysates were prepared and Western blotted with anti-phospho-EGFR (Y845 and Y-992), anti-phospho-Akt (ser-473), anti-Akt, or anti-actin. (C) EGFR ligands are not responsible for constitutive phosphorylation in Calu3 cells. EGFR neutralizing antibodies, LA1 at 12.5, 25 or $50 \mu \mathrm{g}$ were incubated for 18 hours with Calu3 cells with or without 100 ng EGF in the final 5 minutes before lysates were prepared and Western blotted. (D) Transactivation by membrane associated ligands was not responsible for constitutive phosphorylation of EGFR Y-992 or downstream phosphorylation of Akt or Erk1,2. Calu3 cells were serum cultured with Corynebacterium diphtheriae toxin @ $10 \mu \mathrm{g} / \mathrm{ml}, 25 \mu \mathrm{M}$ GM6001, $2.5 \mu \mathrm{M}$ TAPI, $100 \mu \mathrm{M} \mathrm{H}_{2} \mathrm{O}_{2}$, or an equivalent volume of DMSO for 1 hour before lysates were prepared and Western blotted. (E) EGFR neutralizing antibodies blocked phosphorylation in H1975 NSCLC cell line. LAl at $12.5 \mu \mathrm{g}$ was added to H1975 cells for 18 hours. DMSO or 1 MM AG1478 was added for 1 hour. Lysates were prepared for SDS-PAGE and Western blotting with anti-phospho-EGFR(Y-992) and anti-phospho-EGFR (Y-845) or anti-actin. Caco-2 cells (ATCC \#HTB-37, human colorectal adenocarcinoma) served as positive controls for the TACE (ADAM 17) inhibitors, GM6001 and TAPI [35] (data not presented).

increments of EGF neutralizing monoclonal antibody, LA1, from 12.5 to $50 \mu \mathrm{g} / \mathrm{ml}$ failed to inhibit phosphorylation (Figure 1C). LA1, binds the EGFR extracellular domain and competes for binding with ligands; EGF, TGF $\alpha$, and AR. LA1 was effective as it inhibited EGFligand induced Y-992 and Y-845 phosphorylation in H1975 cells (Figure 1E). Thus, phosphorylations regulated by activating mutations in H1975 cell line were susceptible to EGFR kinase inhibitors unlike constitutive phosphorylation in Calu cells.

Potential transactivation by autocrine triggered release of ligands including heparin binding-EGF (HB-EGF) and TNF $\alpha$ by metalloproteases was investigated [31-33]. ADAM17 is responsible for shedding of AR, TGF $\alpha$, EPR, HB-EGF and HRG/NRG ligands from cell membranes [34]. TAPI, a TACE/ADAM17 specific inhibitor, and GM6001 a broad acting matrix metalloproteinase inhibitor, blocked the effects of metalloproteases on EGFR phosphorylation and signaling in Caco-2 control cells [35], but neither GM6001, nor TAPI, nor CRM-197, a diphthotoxin mutant which specifically prevents HB-EGF binding, blocked constitutive phosphorylation of Calu3 cells (Figure 1D). Constitutive activation of EGFR therefore was independent of transactivation via ADAM cleavage of membrane bound ligands and HB-EGF ligand stimulation. Taken together these results demonstrate that constitutive EGFR phosphorylations in Calu3 cells are independent of ligand binding and autophosphorylation. These results directed the study to focus on upstream intracellular kinases as the mechanism for constitutive phosphorylation of EGFR.

\section{Src family kinases (SFK) contribute to constitutive phosphorylation of EGFR}

SFK have been demonstrated in lung tumor tissues [36] and Src phosphorylates EGFR Y-845 in breast cancer 
cells $[29,30]$. The SFK inhibitor, PP2, ablated phosphorylation of EGFR at Y-845 and Y-992, eliminated downstream Akt phosphorylations, and decreased phosphorylated of Erk1,2 in Calu3 cells (Figure 2A). The decrease in EGFR phosphorylation was specific for SFK inhibition as the Mek/Erk1,2 inhibitor U0126 did not inhibit EGFR or Akt phosphorylation, but did block phosphorylation of Erk1,2 as reported. Calu3 cell viability was decreased by inhibition of SFKs in a PP2 concentration dependent manner (Figure 2B). Inhibition of downstream kinase, Akt, with LY29004 revealed a similar concentration-dependent decline in viability while substantially higher concentrations of the EGFR tyrosine kinase inhibitor, erlotinib, were required for an effect on viability. DMSO served as the solvent vehicle control.

Lyn and Src were identified as the major phosphorylated SFK members detected by the Milliplex ${ }^{\circledR}$ luminex assays in Calu3 cell lysates, while Yes was the major phosphorylated SFK member detected in H1975 (Figure 2C). The Milliplex system uses specific antibodies conjugated on beads to capture individual SFK members, followed by a biotinylated anti-
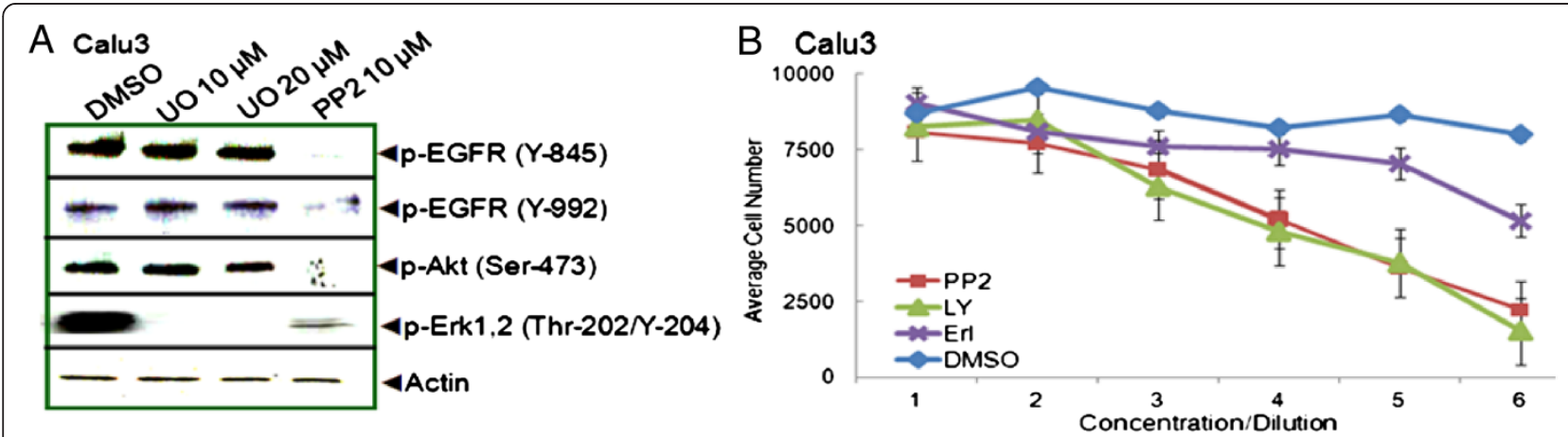

\section{Phosphorylation of Src Family Kinases in Calu3}

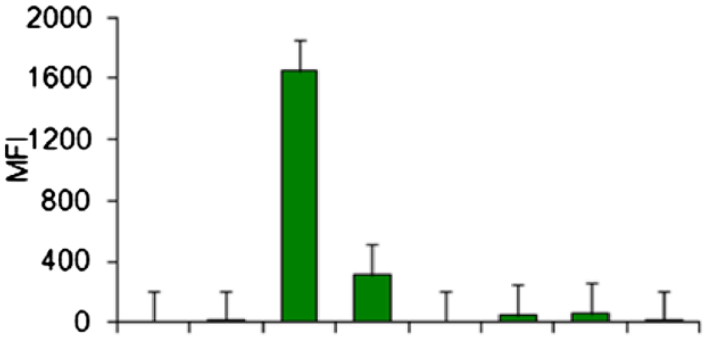

Fyn Blk Src Lyn Fgr Lck Yes Hck

\section{Calu3 \\ WBAntibodies \\ Anti-Yes \\ Anti-Lyn \\ Anti-Fyn \\ Anti-Hck \\ Anti-Src}

E Calu3

Phosphorylation of Src Family Kinases in H1975

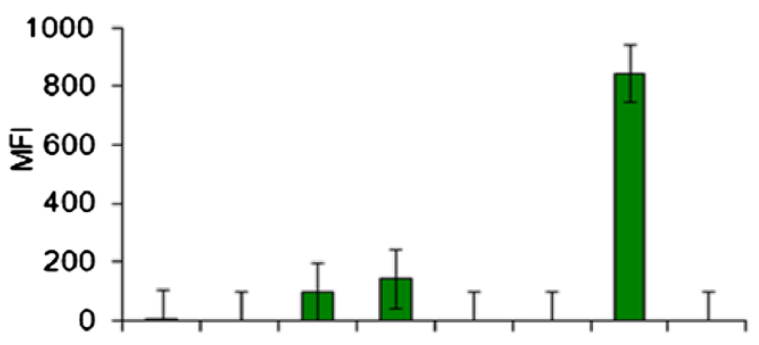

Fyn Blk Src Lyn Fgr Lck Yes Hck

Figure 2 Src Family Kinase (SFK) expression and activation. (A) Src-kinase inhibitor PP2, blocked phosphorylation of EGFR at Y-845 and Y-992 and downstream phosphorylations of Akt and Erk1,2. Calu3 cells were serum starved for 6 hours, then cultured with $10 \mu \mathrm{M}$ PP2, 10 or $20 \mu \mathrm{M}$ U0126, or an equivalent volume of DMSO for 1 hour with addition of recombinant EGF @ $1 \mu \mathrm{g} / \mathrm{ml}$ for the final 10 minutes; then lysates prepared for SDS-PAGE and Western blotting with indicated antibodies. (B) PP2 decreased viability of Calu3 cells in a concentration dependent manner. Calu3 cells were cultured in triplicate in 96-well plates, and serum starved for 8 hours before addition of the respective inhibitors with highest

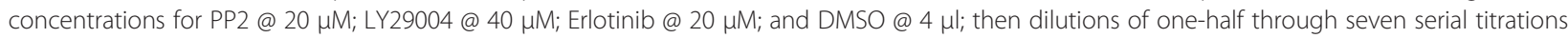
$(7 \rightarrow 1)$. After 70 hours, Calcein AM was added two hours before harvesting. (C) Distinct patterns of SFK activation were revealed in a quantitative Milliplex assay of unstimulated Calu3 and H1975 cell lysates. MFI (median fluorescence intensity) equals sample - background. (D) Expression of phosphorylated Lyn, Src, and an isoform of Fyn in Calu3 cell lysates were confirmed by Western blotting. Anti-phospho-Src (Y-416) immunoprecipitates were blotted and probed separately with anti-SFK member antibodies including Yes, Lyn, Fyn, Hck, and v-Src. Anti-Hck served as a specificity control in that no non-specific bands were observed in either the lysates or IP. (E) Lyn expression and phosphorylation were further confirmed by direct immunoprecipitation. Calu3 cell lysates were incubated with anti-phospho-Src (Y-417), anti-vimentin isotype control or no antibody. Duplicate immunoprecipitations were performed with recombinant protein AlG conjugated beads (PAG) (wells 2,5,7) or TrueBlot ${ }^{\oplus}$ anti-light chain beads (TB, wells 4,6,8). Control immunoprecipitations demonstrated no extraneous bands near mw of SFKs, 58-66 kDa. 
phosphorylation specific antibody to quantitate phosphorylation of the captured Src family member (Figure 2C). Western blotting to identify individual SFK members used a reverse procedure where immunoprecipitations were performed with anti-phosphorylated Src (Y-416), then tested in Western blots with antibodies specific for individual Src family members. Lyn, Src and an isoform of Fyn were detected in immunoprecipitates from Calu3 lysates (Figure 2D). Yes was not phosphorylated while Hck was not detected. Control immunoprecipitations were performed with recombinant protein A/G beads, TrueBlot ${ }^{\circledR}$ antilight chain beads, and isotype antibody controls to rule out nonspecific binding or heavy chain Ig contaminations. Extraneous bands were not observed in the molecular weight range of SFK members in the control immunoprecipitates, while Lyn was readily detected in anti-phospho-Src (Y-416) immunoprecipitates (Figure 2E).

\section{EGFR is physically associated with SFKs, c-Met, and other ErbB chains}

A physical association between phosphorylated EGFR and c-Met was confirmed in Western blots of anti-
phospho-c-Met (Y-1230,1234,1235) immunoprecipitates where phosphorylated ErbB1 chains were pulled down with antibodies to phosphorylated c-Met (Figure 3A). EGFR kinase activity was responsible for c-Met phosphorylation as both erlotinib and AG1478, which target the tyrosine kinase domain of EGFR, inhibited phosphorylation of c-Met (Figure 3B). The inhibition of SFK activity with PP2 also inhibited phosphorylation of c-Met and of ErbB3 supporting an upstream activity for SFKs. The promiscuity of ErbB1 was further confirmed in anti-ErbB3 and anti-ErbB2 immunoprecipitates (Figure 3C). ErbB3 in the immunoprecipitates was activated by phosphorylation at Y1289. The physical association of ErbB1 with c-Met, ErbB2, or ErbB3 expands the network of signaling pathways that are activated in cancer cells and illustrates why a single tyrosine kinase inhibitor may not be sufficient to eradicate disease. An association with SFKs further enhances the spectrum of regulatory factors activated to alter gene expression in lung cancer cells and illustrates the importance of identifying the defining upstream triggering factor or kinase.

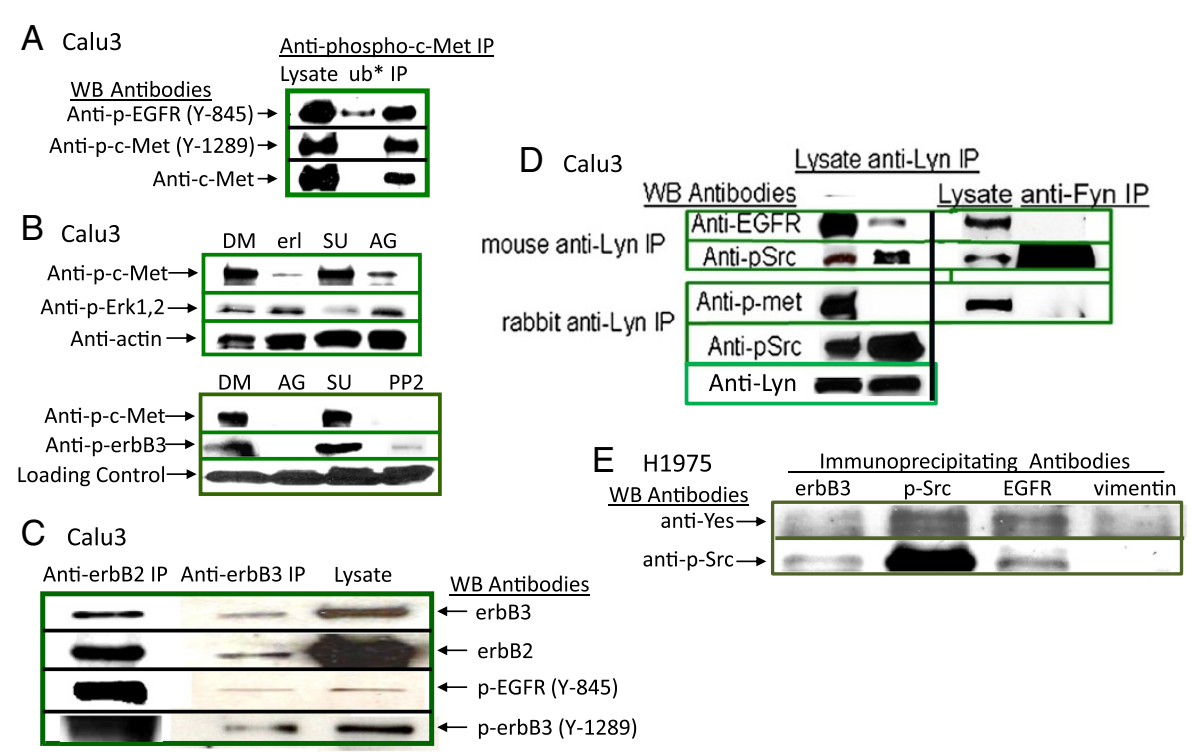

Figure 3 EGFR is physically associated with distinct Src family kinases, c-Met, and other ErbB family members. (A) Phosphorylated c-Met and EGFR from are pulled down together in anti-phospho-c-Met immunoprecipitations. Western blots of unstimulated Calu3 lysates, anti-phospho-c-Met $(\mathrm{Y}-1230,1234,1235)$ immunoprecipitates (IP), and "unbound" (*ub) proteins from IP supernatants were probed with anti-EGFR (Y-845) and anti-c-Met. While all phosphorylated c-Met was pulled down, a portion of phospho-EGFR remained, likely unbound to phosphorylated c-Met. (B) Unstimulated and serum-starved Calu3 cells were cultured with DMSO (DM) or $10 \mu \mathrm{M}$ erlotinib (erl) for 3 hours, and $5 \mu \mathrm{M}$ SU11274 (SU), $1 \mu \mathrm{M}$ AG1478 (AG), or $10 \mu \mathrm{M}$ PP2 for 1 hour before lysates and Western blots were prepared and probed with anti-phospho-c-Met (Y-1230,1234,1235), anti-phospho-Erk1,2 (Thr-202/Y-204), anti-phospho-ErbB3 (Y-1289), or anti-actin. (C) Immunoprecipitation of unstimulated Calu3 Iysates with antiErbB3 also pulled down ErbB2, phosphorylated EGFR, and phosphorylated ErbB3. Anti-ErbB2 reciprocally immunoprecipitated ErbB3 from unstimulated Calu3 lysates. (D) Anti-Lyn pulled down EGFR but not phosphorylated c-Met (Left panels) while anti-Fyn pulled down neither EGFR nor c-Met (Right panels) from unstimulated Calu3 lysates. Western blots of mouse anti-Lyn IPs (top left panel) were probed with anti-EGFR and anti-phospho-Src (Y-416) while rabbit anti-Lyn IPs (lower left panels) were probed with anti-phospho-c-Met $(Y-1230,1234,1235)$ and anti-phospho -Src (Y-416). (E) Yes was associated with EGFR but not ErbB3 in H1975. Lysates from untreated H1975 cells were immunoprecipitated with antibodies to ErbB3, phospho-Src (Y-416), EGFR, and vimentin. Western blots of the IPs were probed with anti-Yes and anti-phospho-Src (Y-416). Anti-vimentin immunoprecipitates served as specificity controls. 
Since Lyn was highly expressed in the Calu3 lung cancer cell line, a role for Lyn in EGFR constitutive phosphorylation was investigated. Anti-Lyn antibodies pulled down EGFR demonstrating their physical association. Phosphorylated c-Met was not evident in anti-Lyn pull downs (Figure 3D). Different species of hosts for anti-Lyn production were used for immunoprecipitations to eliminate potential heavy chain contaminations identified by the secondary antibody in the Western blots, hence mouse antiLyn IPs were probed with rabbit anti-EGFR and pSrc while anti rabbit Lyn IPs were probed with mouse anti-p-c-met, Lyn and pSrc. While a phosphorylated Fyn isoform had been detected by immunoprecipitation, it had no physical association with either EGFR or c-Met (Figure 3D).

Western blots confirmed the presence of phosphorylated Yes in anti-phospho-Src (Y-416) immunoprecipitates of H1975 cell lysates (Figure 3E). Pull-down experiments revealed that EGFR was physically associated with Yes in H1975 cells as Yes was co-immunoprecipitated with anti-EGFR antibodies (Figure 3E). Anti-Vimentin IP served as a specificity control for the co-immunoprecipitations and no Yes or phosphorylated Src were non-specifically pulled down.

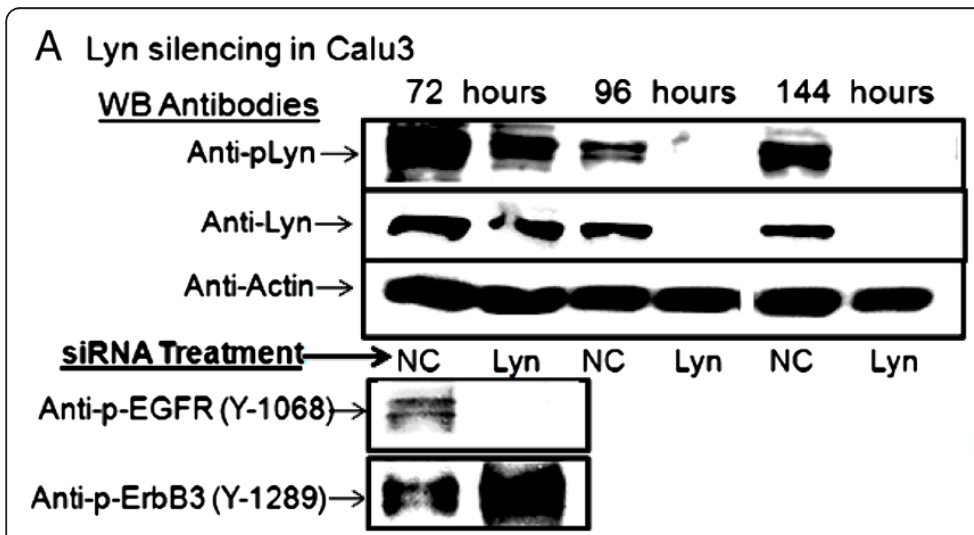

\section{Lyn silencing effect on cell viability}

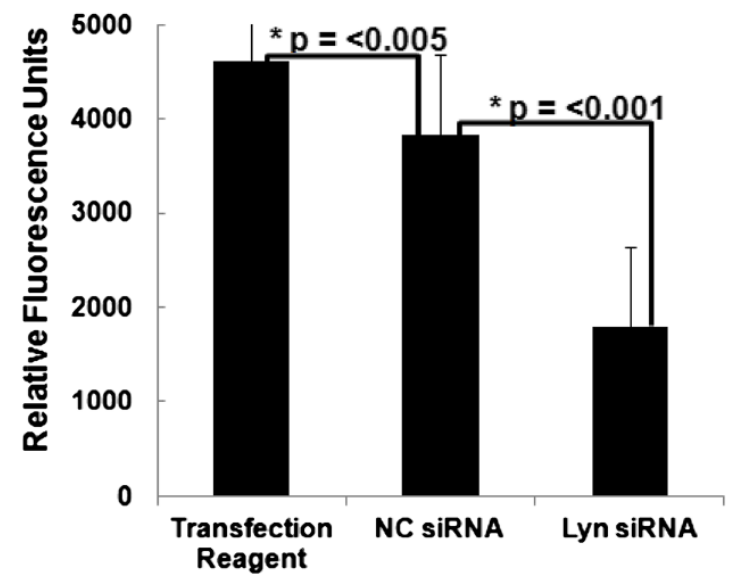

B Lyn silencing of Signaling in Calu3 cells

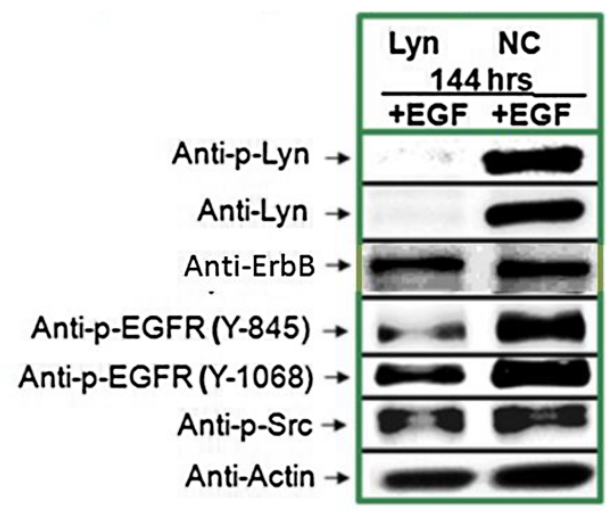

H1975

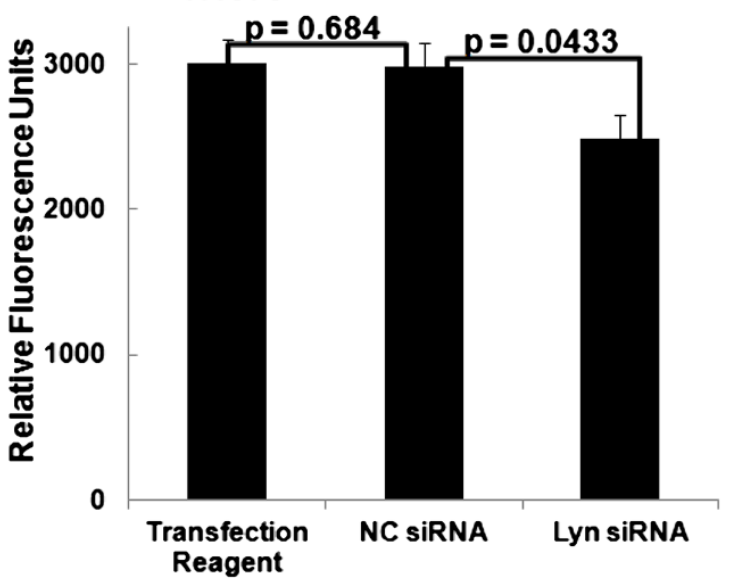

Figure 4 Lyn siRNA inhibits EGFR activation, downstream phosphorylation of c-Met but not phosphorylation of ErbB3. (A) Lyn specific siRNA inhibits Lyn and EGFR phosphorylation. Calu3 cells were cultured with 12.5 nM Lyn siRNA and NC siRNA for 72, 96, and 144 hours before lysates were prepared and $30 \mu \mathrm{g}$ protein from each treatment loaded into SDS-PAGE wells for separation and Western blotting. Blots were probed with anti-phospho-Lyn, anti-Lyn, anti-phospho-EGFR (Y-1068), anti-phospho-ErbB3 (Y-1289), and actin. (B) EGF triggered reexpression and phosphorylation of Lyn was not evident after 144 hours of culture with 12.5 nM Lyn siRNA while NC siRNA had little effect on Lyn or EGFR phosphorylation levels. EGFR phosphorylations were substantially decreased by Lyn siRNA. Serum-starved Calu3 cells were treated with Lyn and NC siRNA, then cultured for 144 hours. EGF at $100 \mathrm{ng} / \mathrm{ml}$ was added for the final 10 minutes before lysates were prepared and $30 \mu \mathrm{g}$ protein from each treatment loaded into SDS-PAGE wells for separation and Western blotting. Multiple blots were probed with antibodies against phospho-Lyn, non-phosphorylated Lyn control, phospho-EGFR (Y-845), phospho-EGFR (Y-1068), non-phosphorylated ErbB control, phospho-Src (Y-416) or $\beta$-actin. (C) Lyn siRNA @ 12.5 nM significantly decreased cell survival after 72 hours of culture. Lyn siRNA decreased viability to highly significant levels, $p=<0.001$ and 0.0433 . Some nonspecific decrease in viability with NC siRNA was also evident but did not reach a similar level of significance. Calcein AM uptake was used to measure cell viability during the last 2 hours of culture. Mann Whitney unit analysis test was applied to relative fluorescent units (RFU) data from 10 replicate wells. 


\section{Lyn contributes to NSCLC viability and signal transduction}

The importance of Lyn to EGFR signaling and cell viability was investigated by treatment of Calu3 cells with pools of 4 Lyn specific silencing RNAs and negative control siRNA. Decreased Lyn phosphorylation and protein expression were demonstrated in Western blots of kinetic studies with Lyn-siRNA transfection (Figure 4A). Decreased Lyn expression and phosphorylation readily inhibited Y-1068 autophosphorylation of EGFR. No decrease in phosphorylation of ErbB3 was observed. EGF stimulation of Calu3 cells after complete Lyn silencing at 144 hours demonstrated no ligand triggered phosphorylation of Lyn, and decreased phosphorylation of EGFR at the SFK-dependent Y845 phosphorylated site, as well as at Y1068 autophosphorylation site (Figure 4B). Lyn, Src, and EGFR phosphorylations remained evident in Calu3 cells transfected with negative control siRNA (Figures 4A and B).

A role for Lyn in cell survival was confirmed in that transfection with Lyn-siRNA significantly decreased unstimulated Calu3 and H1975 cell viability significantly in comparison to nonspecific inhibition of viability with nonspecific control (NC) siRNA (Figure 4C). Thus, Lyn plays a role in maintaining cell viability and signaling.

\section{Activation of Lyn and SFKs}

Inhibition of EGFR phosphorylation by silencing Lyn RNA and a Src kinase specific inhibitor indicated that Src functions upstream to activate EGFR. The possibility that PKC was responsible for phosphorylating Src was investigated with enzastaurin, a serine-threonine kinase inhibitor that preferentially targets $\mathrm{PKC} \beta$. Concentrations of enzastaurin that inhibited $\mathrm{PKC} \alpha, \beta$ phosphorylation led to decreased phosphorylations of EGFR downstream pathways including Akt and GSK-3 $\beta$ (Figure 5A). PKC $\alpha, \beta$ inhibition resulted in total inhibition of Src phosphorylation (Figure 5B). Since enzastaurin has secondary kinase targets, a more specific, cell-permeable, PKC $\beta I I$ peptide inhibitor was used and confirmed that PKC $\beta I I$ was responsible for regulating Src activation (Figure 5C). A PKC 3 II-dependent pathway therefore is responsible for SFK activation in Calu3 cells. Either PKC $3 I$ directly phosphorylates ser12 of Src, or indirectly results from its activation of $\mathrm{CDK} 1 / \mathrm{cdc} 2$, or alternatively inactivates phosphatases that regulate SFK activity [37]. Peptide inhibitors function by binding their targets causing them to unfold, and subsequently become ubiquitinated, and proteosomally digested. The fact that little PKC $\beta I$ protein was detected therefore demonstrates the effective inhibitory nature of the PKC $\beta I$ peptide inhibitor (Figure 4C).

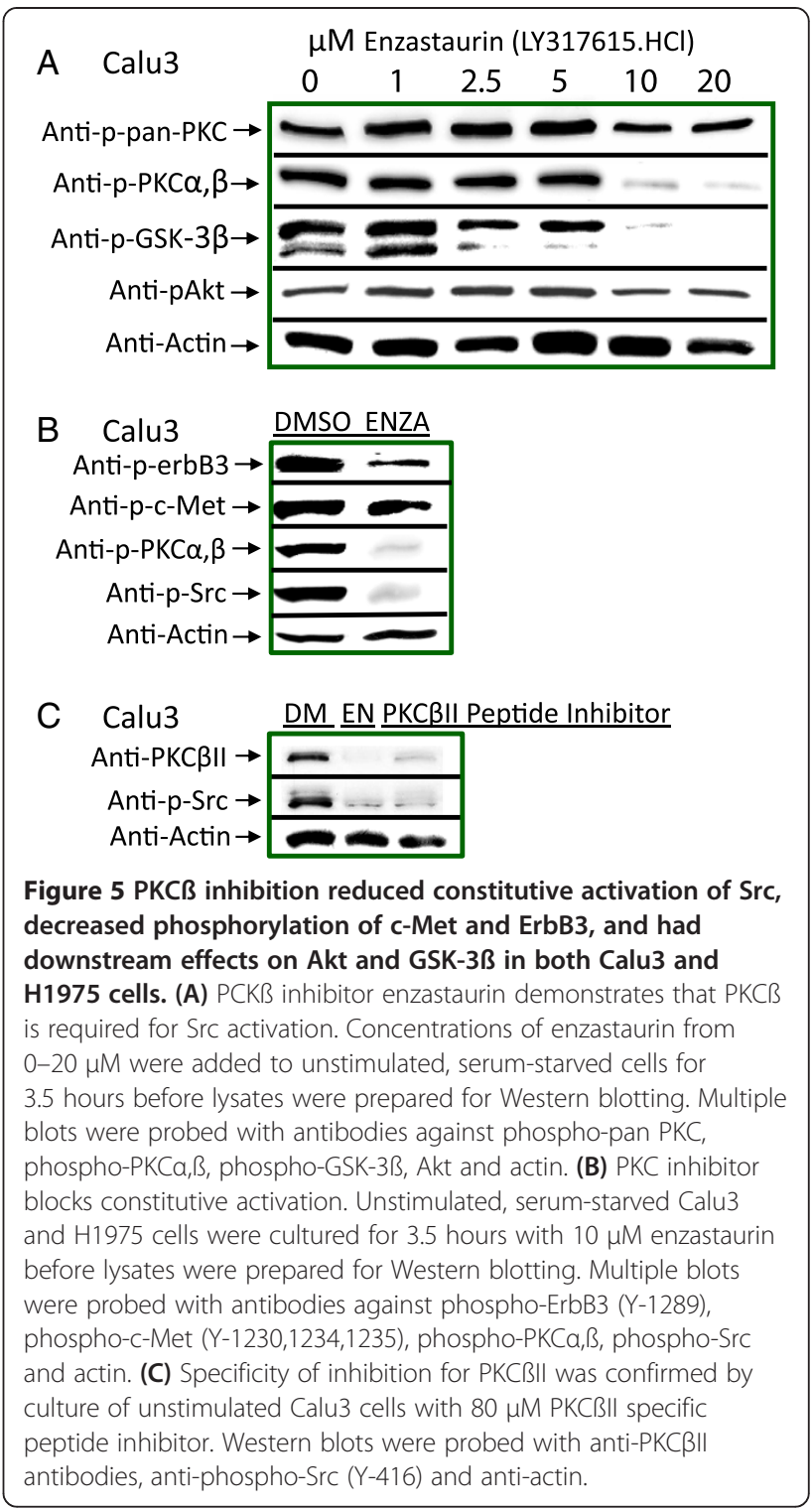

Regulation of EGFR activation occurs in complexes with proteins associated with cell membranes

Membrane scaffolding and Src-regulatory proteins, RACK1 and Cbp/PAG respectively, were investigated to determine whether they were in complexes with EGFR, PKCßII and Lyn. Both RACK1 and Cbp/PAG were detected in four NSCLC lines tested (data not presented) thus, immunoprecipitation experiments were undertaken to determine whether Lyn was associated with EGFR in complexes with Cbp\PAG and/or RACK1. A physical association between Lyn, RACK1, and Cbp/PAG in Calu3 cells was demonstrated in Western blotting of immunoprecipitates (Figure 6). Anti-Lyn co-immunoprecipitated RACK1 and Cbp/PAG. In reciprocal studies, both antiCbp/PAG and anti-RACK1 co-immunoprecipitated each other as well as Lyn (Figure 6A). Anti-Fyn antibodies did 


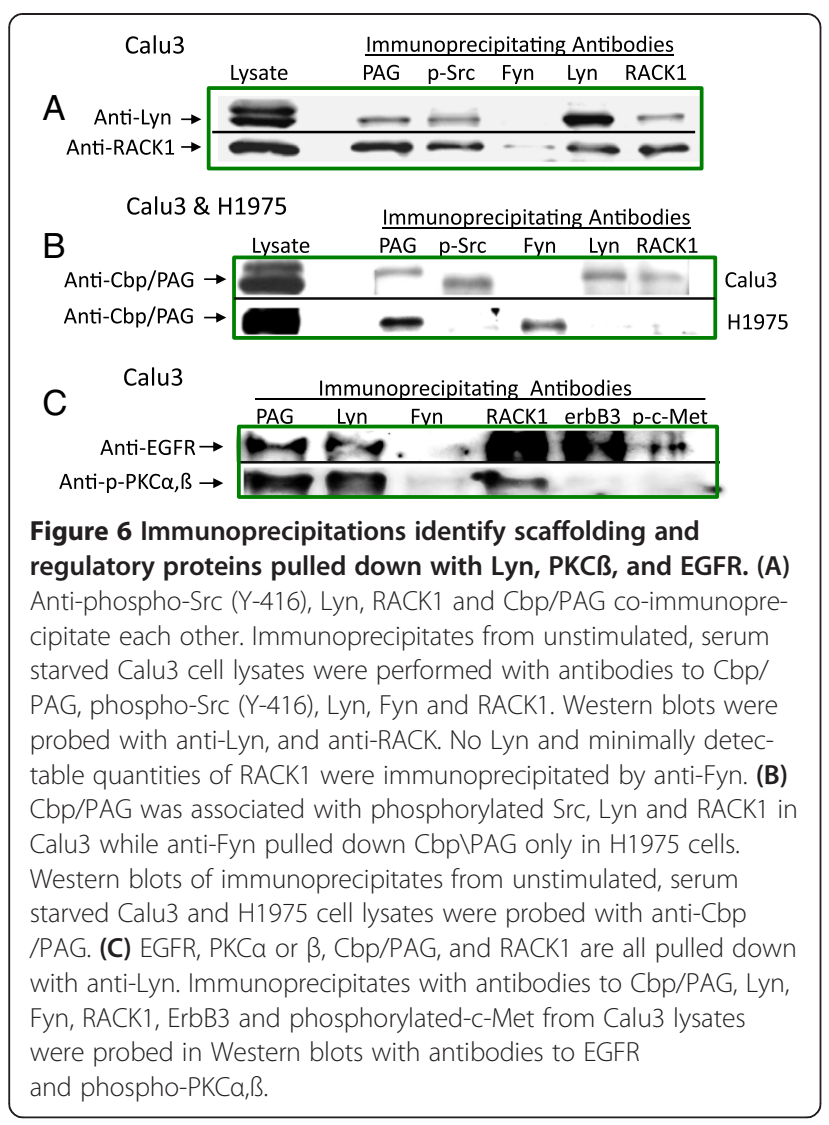

not co-immunoprecipitate Cbp/PAG or RACK1 from Calu3 cell lysates but did co-immunoprecipitate $\mathrm{Cbp} /$ PAG from lysates of H1975 cells (Figure 6B).

EGFR, a plasma membrane receptor, is physically associated with Lyn in Calu3 cells (Figure 3D). Lyn also associates with RACK1 and Cbp\PAG (Figure 6). Furthermore, PKC $\beta I I$ is required for phosphorylations of SFKs that include Lyn (Figure 4C). Thus, a series of pull-down experiments were performed to determine whether PKC, RACK1 and Cbp\PAG exist together with EGFR. Cbp\PAG partitions preferentially into membranes where it also associates with RACK1 which binds activated PKC. PKC $\alpha, \beta$ was localized with Cbp\PAG, RACK1 and Lyn but not with Fyn, ErbB3 or phosphorylated c-Met (Figure 6C). Indeed, anti-Lyn pulled down both phosphorylated PKC $\alpha, \beta$ and EGFR (Figure $6 \mathrm{C}$ ). PKC $\alpha, \beta$ was not detected in complexes reciprocally pulled down by either anti-p-c-Met or ErbB3. These studies thus suggest that EGFR associates with Lyn in membrane complexes of Cbp\PAG and RACK1 where PKCßII can affect Lyn or Src regulatory kinases and phosphatases resulting in activation of Lyn to phosphorylate EGFR and enhance its signaling activity.

\section{Discussion}

The EGFR signal transduction pathway plays an important role in sustaining growth of lung cancer cells, yet therapy with TKIs is effective only in a subset of patients, thus we used lung adenocarcinoma cell lines to investigate mechanisms for constitutive phosphorylation of EGFR in order to identify additional targets for therapy. EGFR constitutive signaling in Calu3 cells was demonstrated to be ligand-independent. ADAM17 protein, an ErbB ligand sheddase, is upregulated and is required for EGFR and ErbB3 ligand-dependent signaling in NSCLC cell lines [38]. Yet, neither GM6001, a broadrange metalloprotease inhibitor, nor TAPI, a potent ADAM17 inhibitor, decreased EGFR phosphorylation at constitutive sites or downstream signaling confirming that cleavage of membrane associated ligands was not responsible for EGFR constitutive phosphorylation. Also, neutralizing antibodies did not block constitutive EGFR activation. Constitutive phosphorylation of EGFR thus was not due to ligand binding or transactivation.

Reportedly, SFKs phosphorylations of EGFR result in enhanced signaling potential $[29,30,39,40]$, and SFKs were found to be responsible for EGFR constitutive activation (Figure 2). Lyn was physically associated with EGFR and identified as the specific SFK responsible for activating EGFR. While Lyn is preferentially expressed in normal and malignant B-cells, Lyn is also found in epithelial cells lining lung alveoli, and lining ducts from mammary, prostate and gut tissues [41-45]. Lyn was recently demonstrated as a requirement for internalization of microbial aggregates in lung epithelial cells and for responses to pathogens [46-48]. Mice deficient in Lyn expression, or transfected to overexpress Lyn, exhibit hyperactive B-cell receptor triggering, autoimmune diseases, and asthma-like symptoms in their lungs thereby emphasizing the importance of Lyn to lung physiology [49-51]. While the role for Lyn in leukemias and lymphomas is well established, a role for Lyn in solid tumors was only recently elaborated. Lyn was found to mediate tumor progression in head and neck squamous cell carcinomas, thyroid cancer growth and metastasis, sarcoma growth and survival, and a prognostic factor in colorectal cancer [52-55]. Lyn may serve therefore as a potential target for therapy in solid tumors.

Phosphorylated EGFR/ErbB1 chains are promiscuous as their physical associations with ErbB3, ErbB2, and c-Met were demonstrated in pull-down experiments (Figures 3 and 6C). These associations have functional consequences as inhibitor studies demonstrated that EGFR is responsible for phosphorylations of c-Met. Heterodimers also complicate EGFR targeted therapy as inhibition of EGFR enhances ErbB2/ErbB3 or EGFR/cMet formation and activation [23,38,40,56]. SFKs also facilitate EGFR and c-Met heterodimer formation, and our 
studies emphasize the importance of SFKs to EGFR activation [Figures 2, 3, 4, 5 and 6] [36,41,42,57,58].

PKCßII was found to be critical to the downstream activation of EGFR, as PKCßII regulates activation of SFKs (Figure 5). PKCßII is known to regulate Src activation via $\mathrm{CDK} 1 / \mathrm{cdc} 2$ and phosphatases [37]. Once activated, PKC becomes bound to the intracellular receptors, RACK1, stabilizing them within membrane lipid rafts where RACK1s then bind enzymes, substrates, growth factor receptors, integrins, and kinases [59-61]. RACK1 has been described as an inhibitory scaffold regulator of Src [62,63]. Activated SFKs and Src-regulatory kinases normally bind to $\mathrm{Cbp} / \mathrm{PAG}$ which associates with glycosphingolipid-enriched microdomains (PAG) in membranes via palmitoylated tails [64-66]. Lyn can also become anchored in membrane lipids via myristoylation and palmitoylation, but in B-lymphomas Lyn has been localized to lipid rafts with Cbp/PAG [51,67-69]. In our studies, Cbp\PAG and Lyn were reciprocally coimmunoprecipitated demonstrating their physical association. A physical association between Lyn and EGFR, PKC $\alpha, \beta, C b p / P A G$, and RACK1 was demonstrated in pull down experiments indicating that multiple signaling molecules form complexes or signalosomes with EGFR. RACK1 molecules can form homodimers with nonidentical proteins bound to each so that one RACK1 partner could carry growth factor receptors such as EGFR, for example, while another could carry Lyn [70]. Alternatively Lyn could be brought into multi-protein complexes bound to Cbp $\backslash$ PAG as RACK1 and Cbp $\backslash$ PAG, Lyn and Cbp\PAG, were all reciprocally co-immunoprecipitated from Calu3 lysates (Figure 6). These data contrast with the EGFR mutationally activated H1975 cells where there was no evidence for co-immunoprecipitation of RACK1 and Cbp\PAG.

The interplay between RACK1 and Cbp $\backslash$ PAG is critical to Src family kinase regulation and to constitutive EGFR activation. Others have demonstrated that RACK1 binds the p110 active component of PI3Kinase, hence could bring PI3Kinase together with EGFR growth factor receptors to trigger downstream signaling [71]. In B-lymphoma lines, the p85 adaptor component of PI3Kinase was shown to bind to activated Cbp\PAG [68]. An association between Cbp $\backslash$ PAG and RACK1 thus could bring the two PI3Kinase components together such that activation of EGFR would trigger the PI3K cascade of signaling events. These latter studies emphasize the importance of scaffolding and $\backslash$ or adaptor proteins that pull receptors and kinases together within membrane complexes so that signals can be transduced. As a scaffolding protein, RACK1 would allow for the kinases to function in a multi-protein complex, and initiate a progression of activity to occur from PKCßII to activate Lyn, Lyn subsequently activating EGFR, followed by activation of PI3 kinase and c-Met, thus resulting in a cascading of signaling events (Figure 7). RACK1's relevance to cancer progression was first demonstrated in breast cancer where its expression serves as an independent prognostic factor for poor outcome [71]. Elevated levels of Rack1 expression have been detected in lung cancer [72], and silencing of RACK1 expression has led to suppressed cancer cell growth and invasion both in vitro and in vivo [71,73]. In lung tumor cells that have ligand-independent, constitutively activated EGFR, targeting of scaffolding proteins such as RACK1 associated signaling complexes could result in the disruption

Lyn Activation of ErbB1/ErbB3/c-Myc Complexes in Plasma Membranes

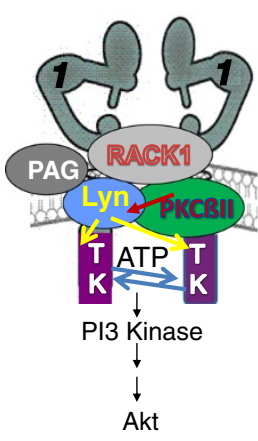

I. ErbB1 homodimers

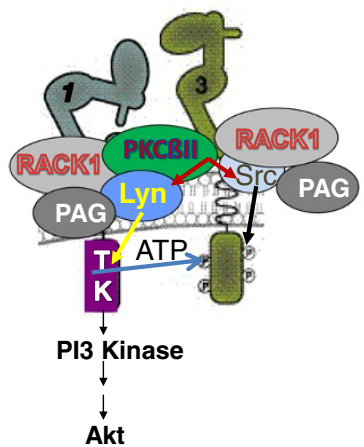

II. ErbB1/ErbB3 heterodimers

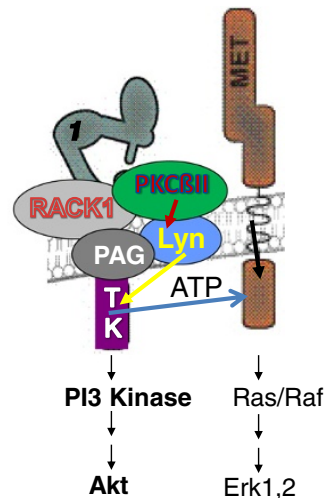

III. ErbB1/c-Met heterodimers

Figure 7 Hypothetical working model of ErbB1 homodimers and heterodimers in lipid rafts with RACK1, PKCßII, Lyn and/or Src, Cbp/ PAG. EGFR/ErbB1 homodimers are drawn together, independent of ligand, within a single RACK1 complex while ligand-independent heterodimers of ErbB1 and ErbB3 or ErbB1 and c-Met may result from the merging of two or more RACK1 complexes. Heterodimers lead to enhanced PI3 kinase activity as illustrated by bolding. 
of their functional capacities. Combining a Src kinase inhibitor with a drug targeting the scaffolding or adaptor proteins along with an EGFR TKI could break up the signaling unit thereby prevent further cell growth. Disruption of EGFR signalosomes could interfere with signaling even when ErbB1 is in promiscuous combinations with other ErbB family members, c-Met, or other receptor chains such as IGFR-1 [74-77]. Combination therapies to include disruption of signaling complexes thus could be a successful approach to eradicate lung cancer cells.

\section{Competing interests}

The authors declare that they have no competing interests.

\section{Authors' contributions}

PS drafted portions of the manuscript and completed the laboratory research for, and constructed, the following figures: Figure 1A-E, Figure 2A, and Figure 3 A-C. Portions of this manuscript served as PS's thesis for completion of a Master's Degree in Medical Laboratory Science. JAB's laboratory carried out the MILLIPLEX ${ }^{\circledR}$ MAP 8-Plex phospho-Src (Tyr419) family kinase immunoassay contributing the data presented in Figure $2 \mathrm{C}$ to define phosphorylated SKF members activated in the Calu3 and H1975 NSCLC cell lines. JAB and JMDP drafted that portion of the manuscript. PB contributed to the concept development by posing the initial question regarding the observation that approximately $50 \%$ of lung cancer patients whose tumors do not have activating EGFR mutations respond to TKI therapy directed against EGFR while another 50\% do not; and provided financial support for the initiation of this project. JMDP's research laboratory generated the vast majority of the data presented in this manuscript. JMDP guided the research by planning the experiments and analyzing the data. JMDP modified the initial draft of the manuscript with additional data, figures, text, analyses, and conclusions thereby completing the manuscript. All authors read and approved the final manuscript.

\section{Acknowledgements}

The authors thank Christopher Forsyth for gracious advice and reagents during the development of this project, Marcherie Davis for outstanding technical assistance and Sanjib Basu for statistical analyses. The research efforts of Illinois Institute of Technology undergraduate students: Ravi Ivengar, and Pavan Rao; are gratefully acknowledged.

\section{Funding}

Funding from Lilly Oncology, and the George W and Lessie K Wadsworth Memorial Fund are acknowledged.

\section{Author details}

${ }^{1}$ Department of Medical Laboratory Sciences, Rush University Medical Center, Chicago, IL 60612, USA. ²Division of Oncology, Department of Medicine, Hematology and Cell Therapy, Rush University Medical Center, Chicago, IL 60612, USA. ${ }^{3}$ Department of Biochemistry, Rush University Medical Center, Chicago, IL 60612, USA. ${ }^{4}$ Department of Immunology \& Microbiology, Rush University Medical Center, Chicago, IL 60612, USA.

Received: 25 June 2012 Accepted: 12 July 2013

Published: 16 July 2013

\section{References}

1. Hirsch FR, Varella-Garcia M, Bunn PA Jr, Di Maria MV, Veve R, Bremmes RM, Baron AE, Zeng C, Franklin WA: Epidermal growth factor receptor in nonsmall-cell lung carcinomas: correlation between gene copy number and protein expression and impact on prognosis. J Clin Oncol 2003, 21(20):3798-3807.

2. Holbro T, Civenni G, Hynes NE: The ErbB receptors and their role in cancer progression. Exp Cell Res 2003, 284(1):99-110.

3. Kanematsu T, Yano S, Uehara H, Bando Y, Sone S: Phosphorylation, but not overexpression, of epidermal growth factor receptor is associated with poor prognosis of non-small cell lung cancer patients. Oncol Res 2003, 13(5):289-298.
4. Sebastian S, Settleman J, Reshkin SJ, Azzariti A, Bellizzi A, Paradiso A: The complexity of targeting EGFR signalling in cancer: from expression to turnover. Biochim Biophys Acta 2006, 1766(1):120-139.

5. Yarden Y, Sliwkowski MX: Untangling the ErbB signalling network. Nat Rev Med Cell Biol 2001, 2(2):127-137.

6. Polosa R, Prosperini G, Leir SH, Holgate ST, Lackie PM, Davies DE: Expression of c-erbB receptors and ligands in human bronchial mucosa. Am J Respir Cell Mol Biol 1999, 20(5):914-923.

7. Fukuoka M, Yano S, Giaccone G, Tamura T, Nakagawa K, Douillard JY, Nishiwaki Y, Vansteenkiste J, Kudoh S, Rischin D, et al: Multi-institutional randomized phase II trial of gefitinib for previously treated patients with advanced non-small-cell lung cancer (The IDEAL 1 Trial). J Clin Oncol 2003, 21(12):2237-2246.

8. Kris MG, Natale RB, Herbst RS, Lynch TJ Jr, Prager D, Belani CP, Schiller JH, Kelly K, Spiridonidis H, Sandler A, et al: Efficacy of gefitinib, an inhibitor of the epidermal growth factor receptor tyrosine kinase, in symptomatic patients with non-small cell lung cancer: a randomized trial. J Am Med Assoc 2003, 290(16):2149-2158.

9. Perez-Soler R, Chachoua A, Hammond LA, Rowinsky EK, Huberman M, Karp D, Rigas J, Clark GM, Santabarbara P, Bonomi P: Determinants of tumor response and survival with erlotinib in patients with non-small-cell lung cancer. J Clin Oncol 2004, 22(16):3238-3247.

10. Sordella R, Bell DW, Haber DA, Settleman J: Gefitinib-sensitizing EGFR mutations in lung cancer activate anti-apoptotic pathways. Sci 2004, 305(5687):1163-1167.

11. Shepherd FA, Rodrigues Pereira J, Ciuleanu T, Tan EH, Hirsh V, Thongprasert S, Campos D, Maoleekoonpiroj S, Smylie M, Martins R, et al: Erlotinib in previously treated non-small-cell lung cancer. N Engl J Med 2005, 353(2):123-132.

12. Bunn PA Jr, Helfrich B, Soriano AF, Franklin WA, Varella-Garcia M, Hirsch FR, Baron A, Zeng C, Chan DC: Expression of Her-2/neu in human lung cancer cell lines by immunohistochemistry and fluorescence in situ hybridization and its relationship to in vitro cytotoxicity by trastuzumab and chemotherapeutic agents. Clin Cancer Res 2001, 7(10):3239-3250.

13. Carpenter G, Cohen S: Epidermal growth factor. J Biol Chem 1990, 265(14):7709-7712

14. Jorissen RN, Walker F, Pouliot N, Garrett TP, Ward CW, Burgess AW: Epidermal growth factor receptor: mechanisms of activation and signalling. Exp Cell Res 2003, 284(1):31-53.

15. Holbrook MR, O'Donnell JB Jr, Slakey LL, Gross DJ: Epidermal growth factor receptor internalization rate is regulated by negative charges near the SH2 binding site Tyr992. Biochem 1999, 38(29):9348-9356.

16. Han SW, Kim TY, Hwang PG, Jeong S, Kim J, Choi IS, Oh DY, Kim JH, Kim DW, Chung DH, et al: Predictive and prognostic impact of epidermal growth factor receptor mutation in non-small-cell lung cancer patients treated with gefitinib. J Clin Oncol 2005, 23(11):2493-2501.

17. Mitsudomi T, Kosaka T, Endoh H, Horio Y, Hida T, Mori S, Hatooka S, Shinoda $M$, Takahashi T, Yatabe Y: Mutations of the epidermal growth factor receptor gene predict prolonged survival after gefitinib treatment in patients with non-small-cell lung cancer with postoperative recurrence. J Clin Oncol 2005, 23(11):2513-2520.

18. Paez JG, Janne PA, Lee JC, Tracy S, Greulich H, Gabriel S, Herman P, Kaye FJ, Lindeman N, Boggon TJ, et al: EGFR mutations in lung cancer: correlation with clinical response to gefitinib therapy. Sci 2004, 304(5676):1497-1500.

19. Pao W, Miller V, Zakowski M, Doherty J, Politi K, Sarkaria I, Singh B, Heelan R, Rusch $V$, Fulton $L$, et al: EGF receptor gene mutations are common in lung cancers from "never smokers" and are associated with sensitivity of tumors to gefitinib and erlotinib. Proc Natl Acad Sciences USA 2004, 101(36):13306-13311.

20. Pao W, Miller VA, Politi KA, Riely GJ, Somwar R, Zakowski MF, Kris MG, Varmus $\mathrm{H}$ : Acquired resistance of lung adenocarcinomas to gefitinib or erlotinib is associated with a second mutation in the EGFR kinase domain. PLoS Med 2005, 2(3):e73.

21. Takano T, Ohe Y, Sakamoto H, Tsuta K, Matsuno Y, Tateishi U, Yamamoto S, Nokihara H, Yamamoto N, Sekine I, et al: Epidermal growth factor receptor gene mutations and increased copy numbers predict gefitinib sensitivity in patients with recurrent non-small-cell lung cancer. J Clin Oncol 2005, 23(28):6829-6837.

22. Engelman JA, Janne PA: Mechanisms of acquired resistance to epidermal growth factor receptor tyrosine kinase inhibitors in non-small cell lung cancer. Clin Cancer Res 2008, 14(10):2895-2899. 
23. Engelman JA, Zejnullahu K, Mitsudomi T, Song Y, Hyland C, Park JO, Lindeman N, Gale CM, Zhao X, Christensen J, et al: MET amplification leads to gefitinib resistance in lung cancer by activating ERBB3 signaling. Sci (New York, NY) 2007, 316(5827):1039-1043.

24. Erjala K, Sundvall M, Junttila TT, Zhang N, Savisalo M, Mali P, Kulmala J, Pulkkinen J, Grenman R, Elenius K: Signaling via ErbB2 and ErbB3 associates with resistance and epidermal growth factor receptor (EGFR) amplification with sensitivity to EGFR inhibitor gefitinib in head and neck squamous cell carcinoma cells. Clin Cancer Res 2006, 12(13):4103-4111.

25. Kobayashi S, Boggon TJ, Dayaram T, Janne PA, Kocher O, Meyerson M, Johnson $B E$, Eck MJ, Tenen DG, Halmos B: EGFR mutation and resistance of non-smallcell lung cancer to gefitinib. N Engl J Med 2005, 352(8):786-792.

26. Massarelli E, Varella-Garcia M, Tang X, Xavier AC, Ozburn NC, Liu DD, Bekele BN, Herbst RS, Wistuba II: KRAS mutation is an important predictor of resistance to therapy with epidermal growth factor receptor tyrosine kinase inhibitors in non-small-cell lung cancer. Clin Cancer Res 2007, 13(10):2890-2896

27. Suda K, Onozato R, Yatabe Y, Mitsudomi T: EGFR T790M mutation: a double role in lung cancer cell survival? J Thorac Oncol 2009, 4(1):1-4.

28. Helfrich BA, Raben D, Varella-Garcia M, Gustafson D, Chan DC, Bemis L, Coldren C, Barón A, Zeng C, Franklin WA, Hirsch FR, Gazdar A, Minna J, Bunn PA Jr: Antitumor activity of the epidermal growth factor receptor (EGFR) tyrosine kinase inhibitor gefitinib (ZD1839, Iressa) in non-small cell lung cancer cell lines correlates with gene copy number and EGFR mutations but not EGFR protein levels. Clin Cancer Res 2006, 12(23):7117-7125.

29. Biscardi JS, Maa MC, Tice DA, Cox ME, Leu TH, Parsons SJ: c-Src-mediated phosphorylation of the epidermal growth factor receptor on Tyr845 and Tyr1101 is associated with modulation of receptor function. JBio/Chem 1999, 274(12):8335-8343.

30. Sato K, Sato A, Aoto M, Fukami Y: c-Src phosphorylates epidermal growth factor receptor on tyrosine 845. Biochem Biophys Res Commun 1995, 215(3):1078-1087.

31. McCole DF, Keely SJ, Coffey RJ, Barrett KE: Transactivation of the epidermal growth factor receptor in colonic epithelial cells by carbachol requires extracellular release of transforming growth factor-alpha. J Biol Chem 2002, 277(45):42603-42612.

32. Prenzel N, Zwick E, Daub H, Leserer M, Abraham R, Wallasch C, Ullrich A: EGF receptor transactivation by $\mathrm{G}$-protein-coupled receptors requires metalloproteinase cleavage of proHB-EGF. Nat 1999, 402(6764):884-888.

33. Roudabush FL, Pierce KL, Maudsley S, Khan KD, Luttrell LM: Transactivation of the EGF receptor mediates IGF-1-stimulated shc phosphorylation and ERK1/2 activation in COS-7 cells. J Biol Chem 2000, 275(29):22583-22589.

34. Hynes NE, Schlange T: Targeting ADAMS and ERBBs in lung cancer. Cancer Cell 2006, 10(1):7-11

35. Forsyth CB, Banan A, Farhadi A, Fields JZ, Tang Y, Shaikh M, Zhang LJ, Engen PA, Keshavarzian A: Regulation of oxidant-induced intestinal permeability by metalloprotease-dependent epidermal growth factor receptor signaling. J Pharmacol Exp Ther 2007, 321(1):84-97.

36. Zhang J, Kalyankrishna S, Wislez M, Thilaganathan N, Saigal B, Wei W, Ma L, Wistuba II, Johnson FM, Kurie JM: SRC-family kinases are activated in nonsmall cell lung cancer and promote the survival of epidermal growth factor receptor-dependent cell lines. Am J Pathol 2007, 170(1):366-376.

37. Roskoski RJ: Src kinase regulation by phosphorylation and dephosphorylation. Biochem Biophys Res Commun 2005, 331(1):1-14.

38. Zhou BB, Peyton M, He B, Liu C, Girard L, Caudler E, Lo Y, Baribaud F, Mikami I, Reguart N, et al: Targeting ADAM-mediated ligand cleavage to inhibit HER3 and EGFR pathways in non-small cell lung cancer. Cancer Cell 2006, 10(1):39-50.

39. Belsches-Jablonski AP, Biscardi JS, Peavy DR, Tice DA, Romney DA, Parsons SJ: Src family kinases and HER2 interactions in human breast cancer cell growth and survival. Oncogene 2001, 20(12):1465-1475.

40. Ishizawar RC, Miyake T, Parsons SJ: c-Src modulates ErbB2 and ErbB3 heterocomplex formation and function. Oncogene 2007, 26(24):3503-3510.

41. Scapini P, Pereira S, Zhang H, Lowell CA: Multiple roles of Lyn kinase in myeloid cell signaling and function. Immunol Rev 2009, 228(1):23-40.

42. Hibbs ML, Dunn AR: Lyn, a src-like tyrosine kinase. Int J Biochem Cell Biol 1997, 29(3):397-400.

43. Zucchi I, Prinetti A, Scotti M, Valsecchi V, Valaperta R, Mento E, Reinbold R, Vezzoni P, Sonnino S, Albertini A, et al: Association of rat8 with Fyn protein kinase via lipid rafts is required for rat mammary cell differentiation in vitro. ProcNat/AcadSciUSA 2004, 101(7):1880-1885.
44. Siyanova EY, Serfas MS, Mazo IA, Tyner AL: Tyrosine kinase gene expression in the mouse small intestine. Oncogene 1994, 9(7):2053-2057.

45. Park SI, Zhang J, Phillips KA, Araujo JC, Najjar AM, Volgin AY, Gelovani JG, Kim S-J, Wang Z, Gallick GE: Targeting Src family kinases inhibits growth and lymph node metastases of prostate cancer in an orthotopic nude mouse model. Cancer Res 2008, 68(9):3323-3333.

46. Lepanto P, Bryant DM, Rossello J, Datta A, Mostov KE, Kierbel A: Pseudomonas aeruginosa interacts with epithelial cells rapidly forming aggregates that are internalized by a Lyn-dependent mechanism. Cell Microbiol 2011, 13(8):1212-1222.

47. Kannan S, Audet A, Knittel J, Mullegama S, Gao GF, Wu M: Src kinase Lyn is crucial for Pseudomonas aeruginosa internalization into lung cells. Eur J Immunol 2006, 36(7):1739-1752.

48. Kannan S, Audet A, Huang H, Chen L-j, Wu M: Cholesterol-rich membrane rafts and Lyn are involved in phagocytosis during pseudomonas aeruginosa infection. J Immunol 2008, 180(4):2396-2408

49. Hibbs ML, Harder KW, Armes J, Kountouri N, Quilici C, Casagranda F, Dunn $A R$, Tarlinton DM: Sustained activation of Lyn tyrosine kinase in vivo leads to autoimmunity. J Exp Med 2002, 196(12):1593-1604.

50. Hibbs ML, Tarlinton DM, Armes J, Grail D, Hodgson G, Maglitto R, Stacke SA, Dunn AR: Multiple defects in the immune system of Lyn-deficient mice, culminating in autoimmune disease. Cell 1995, 83(2):301-311.

51. Xu Y, Harder KW, Huntington ND, Hibbs ML, Tarlinton DM: Lyn tyrosine kinase: accentuating the positive and the negative. Immun 2005, 22(1):9-18.

52. Wheeler SE, Morariu EM, Bednash JS, Otte CG, Seethala RR, Chiosea SI, Grandis JR: Lyn kinase mediates cell motility and tumor growth in EGFRvill-expressing head and neck cancer. Clin Cancer Res 2012, 18(10):2850-2860

53. Chan CM, Jing S, Pike LA, Zhou Q, Lim DJ, Sams SB, Lund GS, Sharma V, Haugen BR, Schweppe RE: Targeted inhibition of Src kinase with dasatinib blocks thyroid cancer growth and metastasis. Clin Cancer Res 2012, 18(13):3580-3591.

54. Bai Y, Li J, Fang B, Edwards A, Zhang G, Bui M, Eschrich S, Altiok S, Koomen J, Haura EB: Phosphoproteomics identifies driver tyrosine kinases in sarcoma cell lines and tumors. Cancer Res 2012, 72(10):2501-2511.

55. Su N, Peng L, Xia B, Zhao Y, Xu A, Wang J, Wang Y, Jiang B: Lyn is involved in CD24-induced ERK1/2 activation in colorectal cancer. Mol Cancer 2012, 11:43.

56. Engelman JA, Janne PA, Mermel C, Pearlberg J, Mukohara T, Fleet $C$ Cichowski K, Johnson BE, Cantley LC: ErbB-3 mediates phosphoinositide 3-kinase activity in gefitinib-sensitive non-small cell lung cancer cell lines. Proc Natl Acad Sci 2005, 102(10):3788-3793.

57. Jo M, Stolz DB, Esplen JE, Dorko K, Michalopoulos GK, Strom SC: Cross-talk between epidermal growth factor receptor and c-Met signal pathways in transformed cells. J Biol Chem 2000, 275(12):8806-8811.

58. Yamamoto N, Mammadova G, Song RX-D, Fukami Y, Sato K-i, Yamamoto N, Mammadova G, Song RX-D, Fukami Y, Sato K-i: Tyrosine phosphorylation of p145met mediated by EGFR and Src is required for serum-independent survival of human bladder carcinoma cells. J Cell Sci 2006, 119 (22):4623-4633.

59. Ron D, Chen CH, Caldwell J, Jamieson L, Orr E, Mochly-Rosen D: Cloning of an intracellular receptor for protein kinase C: a homolog of the beta subunit of G proteins. Proc Natl Acad Sci USA 1994, 91(3):839-843.

60. Chang BY, Chiang M, Cartwright CA: The interaction of SrC and RACK1 is enhanced by activation of protein kinase $C$ and tyrosine phosphorylation of RACK1. J Biol Chem 2001, 276(23):20346-20356.

61. Zhang W, Zong CS, Hermanto U, Lopez-Bergami P, Ronai Z, Wang LH: RACK1 recruits STAT3 specifically to insulin and insulin-like growth factor 1 receptors for activation, which is important for regulating anchorageindependent growth. Mol Cell Biol 2006, 26(2):413-424.

62. Mamidipudi V, Cartwright CA: A novel pro-apoptotic function of RACK1: suppression of Src activity in the intrinsic and Akt pathways. Oncogene 2009, 28(50):4421-4433.

63. Chong YP, la KK, Mulhern TD, Cheng HC: Endogenous and synthetic inhibitors of the Src-family protein tyrosine kinases. Biochim Biophys Acta 2005, 1754(1-2):210-220

64. Brdicka T, Pavlistova D, Leo A, Bruyns E, Korinek V, Angelisova P, Scherer J, Shevchenko A, Shevchenko A, Hilgert I, et al: Phosphoprotein Associated with Glycosphingolipid-Enriched Microdomains (Pag), a novel ubiquitously expressed transmembrane adaptor protein, binds the protein tyrosine kinase Csk and is involved in regulation of $\mathrm{T}$ cell activation. The J of Expt/ Med 2000, 191(9):1591-1604 
65. Oneyama C, Hikita T, Enya K, Dobenecker MW, Saito K, Nada S, Tarakhovsky A, Okada M: The lipid raft-anchored adaptor protein Cbp controls the oncogenic potential of c-Src. Mol Cell 2008, 30(4):426-436.

66. Ingley E: Src family kinases: regulation of their activities, levels and identification of new pathways. Biochim Biophys Acta (BBA) - Proteins \& Proteomic 2008, 1784(1):56-65.

67. Yasuda K, Nagafuku M, Shima T, Okada M, Yagi T, Yamada T, Minaki Y, Kato A, Tani-Ichi S, Hamaoka T, et al: Cutting edge: Fyn is essential for tyrosine phosphorylation of Csk-binding protein/phosphoprotein associated with glycolipid-enriched microdomains in lipid rafts in resting T cells. J Immunol 2002, 169(6):2813-2817.

68. Tauzin S, Ding H, Burdevet D, Borisch B, Hoessli DC: Membrane-associated signaling in human B-lymphoma lines. Exp Cell Res 2011, 317(2):151-162.

69. Tauzin $S$, Ding $H$, Khatib K, Ahmad I, Burdevet D, van Echten-Deckert $G$, Lindquist JA, Schraven B, N-u D, Borisch B, et al: Oncogenic association of the $\mathrm{Cbp} / \mathrm{PAG}$ adaptor protein with the Lyn tyrosine kinase in human B-NHL rafts. Blood 2008, 111(4):2310-2320.

70. Thornton C, Tang K-C, Phamluong K, Luong K, Vagts A, Nikanjam D, Yaka R, Ron D: Spatial and temporal regulation of RACK1 function and N-methyl -D-aspartate receptor activity through WD40 motif-mediated dimerization. J Biol Chem 2004, 279(30):31357-31364.

71. Cao X-X, Xu J-D, Xu J-W, Liu X-L, Cheng Y-Y, Wang W-J, Li Q-Q, Chen Q, Xu Z-D, Liu X-P: RACK1 promotes breast carcinoma proliferation and invasion/metastasis in vitro and in vivo. Breast Cancer Res Treat 2010 123(2):375-386.

72. Nagashio $R$, Sato $Y$, Matsumoto $T$, Kageyama $T$, Satoh $Y$, Shinichiro $R$, Masuda N, Goshima N, Jiang S-X, Okayasu I: Expression of RACK1 is a novel biomarker in pulmonary adenocarcinomas. Lung Cancer 2010, 69:54-59.

73. Wang F, Osawa T, Tsuchida R, Yuasa Y, Shibuya M: Down-regulation of RACK1 suppresses tumor growth by inhibiting tumor cell proliferation and tumor-associated angiogenesis. Cancer Sci 2011, 102:2007-2013.

74. Choi Y, Rho J, Jeon B-S, Choi S, Park S, Lee S, Kim H-R, Kim C, Lee J: Combined inhibition of IGFR enhances the effects of gefitinib in H1650: a lung cancer cell line with EGFR mutation and primary resistance to EGFR-TK inhibitors. Cancer Chemother Pharmacol 2010, 66(2):381-388.

75. Ludovini V, Bellezza G, Pistola L, Bianconi F, Di Carlo L, Sidoni A, Semeraro A Del Sordo R, Tofanetti FR, Mameli MG, et al: High coexpression of both insulin-like growth factor receptor-1 (IGFR-1) and epidermal growth factor receptor (EGFR) is associated with shorter disease-free survival in resected non-small-cell lung cancer patients. Ann Oncol 2009, 20(5):842-849.

76. Pallis A, Briasoulis E, Linardou H, Papadimitriou C, Bafaloukos D, Kosmidis P, Murray S: Mechanisms of resistance to epidermal growth factor receptor tyrosine kinase inhibitors in patients with advanced non-small-cell lung cancer: clinical and molecular considerations. Curr Med Chem 2011, 18(11):1613-1628.

77. Yang L, Li J, Ran L, Pan F, Zhao X, Ding Z, Chen Y, Peng Q, Liang H: Phosphorylated insulin-like growth factor 1 receptor is implicated in resistance to the cytostatic effect of gefitinib in colorectal cancer cells. J Gastrointest Surg 2011, 15(6):942-957.

doi:10.1186/1476-4598-12-76

Cite this article as: Sutton et al: Lyn, a Src family kinase, regulates activation of epidermal growth factor receptors in lung adenocarcinoma cells. Molecular Cancer 2013 12:76.

\section{Submit your next manuscript to BioMed Central and take full advantage of:}

- Convenient online submission

- Thorough peer review

- No space constraints or color figure charges

- Immediate publication on acceptance

- Inclusion in PubMed, CAS, Scopus and Google Scholar

- Research which is freely available for redistribution

Submit your manuscript at www.biomedcentral.com/submit 